Karolina Szuma*

\title{
The imposition of an increased environmental fee for operating without a required permit or another administrative decision, and the cause of the absence of the permit or decision
}

\section{Wymierzenie opłaty podwyższonej za korzystanie ze środowiska bez wymaganego pozwolenia lub innej decyzji a przyczyna braku pozwolenia}

\section{Abstract}

As long as the applicant files an application for a new permit well in advance, before the expiry of the existing permit, and allowing enough time for the application to

" Doctor of laws, Assistant Professor at European School of Law and Administration in Warsaw, Studio Legale Dr Karolina Szuma Office of Legal Counsel in Poznań. 


\section{Karolina Szuma}

be processed, and the new permit is not issued before the expiry of the existing one because of reasons attributable to the administrative body (such as its inaction or tardy proceedings), the issuance of a decision, referred to in article 193 section $4 \mathrm{EPA}$, is relevant for the holder of the existing permit. What follows is that the environmental fee should be paid at the rate applicable during the period of the previous permit from the moment of its expiry until the new one is obtained. It may therefore be found inadmissible to make an entity liable for the tardiness of administrative proceedings by imposing on it the increased environmental fees.

Key words: Increased environmental fee; operating without a required permit

\section{Streszczenie}

W artykule uwaga została skierowana na opłaty za korzystanie ze środowiska, w szczególności na opłaty podwyższone w kontekście nieuzyskania pozwolenia przez dany podmiot z przyczyn niezależnych od tego podmiotu. Podkreślono, że w okresie pomiędzy upływem terminu ważności dotychczasowego pozwolenia a uzyskaniem nowego pozwolenia, opłata za korzystanie ze środowiska ponoszona powinna być w wysokości dotychczasowej, a więc takiej, która obowiązywała w okresie ważności pozwolenia. Niedopuszczalne bowiem może być obciążanie podmiotu korzystającego ze środowiska ujemnymi konsekwencjami opieszałego lub przewlekłego prowadzenia postępowania administracyjnego $\mathrm{W}$ postaci podwyższonych opłat za korzystanie ze środowiska.

Słowa kluczowe: Opłata podwyższona za korzystanie ze środowiska; korzystanie ze środowiska bez wymaganego pozwolenia

Polish environmental legislation provides for various financial and legal environmental protection measures. They include, in particular, environmental fees, administrative fines, and varied rates of taxes and other public levies serving the purposes of environmental protection (article 272 Environmental Protection Act of 27 April 2001').

The focus of this study is on the environmental fees, including, in particular, the increased fees imposed when an entity fails to obtain the permit for reasons beyond its control. 
The general principle is that the environmental fee is imposed for releasing gases or dust to the atmosphere, discharging sewage to water or soil, water intake, and waste storage.

It is also prescribed that the rate of the environmental fee depends on the following:

(1) the quantity and type of gases or dust released to the atmosphere;

(2) the distance from and quality of the drawn water; whether ground or surface water is drawn, as well as the purpose for which the water is drawn.

As regards sewage discharge, the rate depends on the substances contained in the sewage and their quantity, type of sewage, and, in the case of cooling water, its temperature. The rate of the fee for discharging sewage also depends on the surface area and type of the land from which the sewage is released, as well as how the land is used. Other determinants include the type and quantity of the substances in the sewage or the quantity of produced fish other than Salmonidae or other water organisms.

The waste storage fee depends on the quantity and type of the deposited waste; in the case of the increased fee, the rate also depends on the duration of waste storage.

The environmental fees are applicable to entities that exploit the natural environment. Such an entity is obligated to establish the due rate in its own capacity, and pay the fee to the bank account of the relevant Province Marshall's Office.

An entity exploiting the environment without obtaining the required permit or another administrative decision is obligated to pay the increased environmental fee.

Pursuant to article $292 \mathrm{EPA}$, if an entity is exploiting the environment without the permit, it is obligated to pay a fee at the rate of $500 \%$ of the standard rate for:

(1) releasing gases or dust to the atmosphere;

(2) drawing water or releasing sewage to water or soil;

For the waste storage without obtaining an administrative approval for a landfill management plan, in principle the entity concerned is liable to pay an increased fee at the rate of 0.05 of the single landfill fee rate for each day of waste storage. Waste warehousing without obtaining an administrative decision specifying the manner and place of waste storing is deemed to be waste storage without an administrative approval for a landfill operation plan. For storing waste at a site not designated for the purpose, an entity 


\section{Karolina Szuma}

is liable to pay an increased fee at the rate of 0.7 of the single landfill fee for each tonne of waste and each day of waste storage.

If waste is disposed of:

(1) on the shores of water reservoirs, in particular in protected water intake zones and areas of water outflow from aquifers;

(2) in national parks and nature reserves; or

(3) in forest and/or health resort areas or leisure areas;

an entity exploiting the environment is liable to pay an increased fee at the rate of 1.0 of the single landfill fee for each tonne of waste and each day of waste storage.

If an entity exploiting the environment disposes of waste into inland surface or ground waters, internal sea waters or territorial seas, it is liable to pay an increased fee at an amount equal to the single landfill fee multiplied by a factor of 100 . The increased fee is payable on prior to the landfill storage fee.

Pursuant to article 276(1) EPA, an entity exploiting the environment without obtaining the required permit or another administrative decision is liable to pay the increased environmental fee. Provided that the obligation to pay the fee is connected with operating an installation, the fee for emissions, referred to in article 180 section 1 to 180 section 3 , is to be paid by the installation operator (article 279 section 1 point $1 \mathrm{EPA}$ ).

There are no grounds for imposing an increased fee, if there is no substantive law basis to impose one. This refers to the case where an entity's operation without the permit is, to a great extent, due to the competent body's failure to establish the relevant facts necessary to determine the causes of the environmental fees being paid by an entity that holds no permit or legal title to the installation concerned. It should be stressed that the purpose of the increased fee imposition is to motivate an entity to obtain the required permit.

The Supreme Administrative Court ruled on related matters in its judgments of 1 June $2010^{2}$ and 20 April $2010^{3}$.

In the justifications of these judgments, the Court argued that "to define the term 'absence of the required permit', a systemic interpretation should be applied. We need to take into consideration the causes of the absence $[\ldots]$ and establish the facts that led to it. Considering the facts

2 II OSK 871/09.

3 II OSK 785/09. 
of the case, it is clear that the claimant company is not liable for the absence of the sector permit as the absence is the consequence of the protracted proceedings of the competent administrative authority". The Court also stated that "the claimant company has proved the likelihood of it not being liable for the absence of the permit [...], as the reason for it was the protracted examination of the case by the competent body. It should be remarked in passing that the increased environmental fee imposed in the case is contrary to the constitutional principles of the rule of law enshrined in article 2 and article 7 of the Constitution of the Republic of Poland of 2 April 1997."

Moreover, the prevailing view in case law and jurisprudence is that, within the meaning of the Environmental Protection Act, the increased fees are a financial sanction imposed on an entity exploiting the environment, if it, for example, improperly treats waste, releases gases and dust into the atmosphere, draws water, or releases sewage to water or soil (article 292 in conjunction with article $293 \mathrm{EPA}^{5}$ ). The imposition of the increased fee, referred to in article 292 section 1 EPA, is mandatory, if an entity exploiting the environment does not hold the required permit. It has been suggested in the legal doctrine that there are no grounds, whatsoever, to waive the obligation to pay the increased fees, which can be inferred from both the grammatical interpretation of article 296 section 1 and article $292 \mathrm{EPA}$, and the principle of lawfulness, which states that administrative bodies are ex officio obligated to observe the law $^{6}$. The case law literature underlines that since the relevant regulations do not provide for a possibility to waive the obligation to pay the increased fees, the legislature simply did not intend to introduce such a possibility, and it cannot be inferred from the regulations. However, despite taking the available legal measures, a party that has suffered a loss, as the consequence of the action or inaction of an administrative body, will be able to seek damages from the State

4 Journal of Laws of 1997, No 78, item 483 with amendments (the Polish Constitution). A. Kiersnowska-Drzewiecka, Optaty za korzystanie ze środowiska jako koszt uzyskania przychodów, Doradca Podatkowy 2013 No 2, p. 23, K. Euczak, Glosa do uchwaty NSA z dnia 12 grudnia 2011 r., II OPS 2/11, Glosa 2012, No 4, p. 106, P. Sadowski, Optata podwyższona jako konsekwencja braku pozwolenia wodnoprawnego, Casus 2009, No 4, p. 27.

6 K. Gruszecki, Komentarz do art. 276 ustawy - Prawo ochrony środowiska, Lex el. 1 June 2011, referred to as: K. Gruszecki, Komentarz do art. 276 ustawy. 


\section{Karolina Szuma}

Treasury or a local self-government unit or another legal person exercising the authority under law, pursuant to article 417 of the Civil Code ${ }^{78}$.

The Supreme Administrative Court took a position on the legal nature of the obligation to pay the increased fees in its judgment of 17 March $2006^{9}$, in which it stated that Article 276(1) EPA "does not make the obligation to pay increased fees dependent on the reasons why an entity exploiting the environment without a required permit fails to meet this requirement. Neither does it empower the competent body obligated to determine the amount of increased fees to refrain from determining such fees because of the actions of another body or legal acts issued by it".

It is irrelevant for the imposition of the increased fee that the entity concerned has been paying the environmental fees despite the absence of the integrated permit ${ }^{10}$.

However, the view under discussion and expressed in case law and jurisprudence, while reasonable, cannot be deemed correct in the end. One cannot shift responsibility onto an entrepreneur for the tardiness of public administration $^{11}$.

One notable piece of case law is a resolution taken by seven justices of the Supreme Administrative Court of 12 December $2012^{12}$, at the request of the Civil Rights Ombudsman, who asked the following legal question: "In a case regarding the imposition of an increased fee for exploiting the environment without permit (article 276 section 1 of the Environmental Protection Act of 27 April 2001, Journal of Laws of 2008, No. 25, item 150 as amended), is the exploitation of the environment without permit a sufficient ground in its own right for imposing the fee or should the relevant administration body examine the causes of the absence of the permit as well?". The Court replied that the cause of the absence of the permit may be relevant, if an entity exploiting the environment under the existing permit applied for a permit for the subsequent period.

The Civil Code of 23 April 1964, Journal of Laws of 2014, item 121.

Ibidem.

9 II OSK 646/05.

10 See: Voivodeship Administrative Court judgment of 7 September 2011, IV SA/Po 565/11.

11 See: Odpowiedzialnośc administracji $i$ w administracji, eds. M. Stahl, Z. Duniewska, Warszawa 2013, J. Parchomiuk, Odpowiedzialnośc odszkodowawcza za legalne dziatania administracji publicznej, Warszawa. 2007.

12 II OPS 2/11. 
The major points raised in the resolution of the Supreme Administrative Court should be discussed below.

The administrative court judgments cited by the Civil Rights Ombudsman in the request pointed out the inconsistencies in the case law produced by administrative courts. The inconsistencies generally concern two types of situations. The first is where the obligation to pay the increased fee, under article 276 section $1 \mathrm{EPA}$, applies to an entity exploiting the environment while holding a permit, and has applied for a permit for the subsequent period, but the new permit has not been issued before the expiry of the previous one. The other instance is when the entity concerned does not hold a required permit and is exploiting the environment without it or without other applicable administrative decision.

There are no doubts about the application of article 276 section 1 EPA in the latter situation, i.e. where an entity engages in an activity involving the exploitation of the environment without any permit. Doubts arise, however, as to the application of this provision where an entity exploiting the environment holds a permit valid for a specified time and, after its expiry, continues to exploit the environment pending the grant of a permit for the subsequent period. For this reason, an explanation of article 276 section 1 EPA should address this situation, especially that the justification of the Ombudsman's request suggested that the doubts about the application of the provision concerned not just any cause of the absence of a permit, but a specific cause: the tardiness of proceedings conducted by a competent administration body as a consequence of which the existing permit expires before a permit for the subsequent period is issued.

The Court points out that certain fundamental issues should be considered when explaining the provision of article 276 section 1 EPA.

Firstly, it has to be stated that, under article 276 section 1 EPA, any entity exploiting the environment without obtaining the required permit or any other required administrative decision is liable to pay the increased environmental fee. This means that by this provision, the legislature did not introduce any other substantive law premises for a competent public administrative body to issue a decision imposing the increased fee on that basis. For this reason, in explaining the provisions identified in the request of the Civil Rights Ombudsman, the Court had to assess whether the legislators provided for other grounds for this in other provisions of procedural or substantive administrative law. 


\section{Karolina Szuma}

Secondly, the Court points out that at present the Environmental Protection Act includes article 209 section 2. It lays down that if the integrated permit is to be issued for the operation of an installation for the first time or after its material modification, the permit should be issued within six months from the application date. Furthermore, article 35 section 5 of the Code of Administrative Proceedings ${ }^{13}$ applies accordingly. It is therefore an exception that the legislature introduced intentionally when setting the time limit for the grant of the integrated permit, taking into consideration that the integrated permit, as defined in article 201 section $1 \mathrm{EPA}$, is required for the operation of an installation which may, because of its kind and scale, cause serious pollution of the individual components of the environment or even the environment as a whole. This means that once an interested entity files an application, which not only has to meet the requirements for a permit as defined in article 181 section $1 \mathrm{EPA}$ (the so-called sector permit), but also all other requirements provided for in article 208 section 2 to 208 section $7 \mathrm{EPA}$, the competent administration body is obligated to carry out a detailed inquiry.

Thirdly, what also needs to be examined is whether the competent body is able to examine other facts in the consequence of which an entity exploiting the environment holds no required permit or another administrative decision or whether the body is bound to automatically calculate and impose the increased fee. The increased fee is, after all, an administrative sanction for a violation of the prohibition against releasing substances or energy to the environment without a legally required permit (article 181 section $1 \mathrm{EPA}$ ).

According to the Supreme Administrative Court, the causes, as well as the legal and factual circumstances of an administration body's failure to examine such a case in a timely manner cannot be completely ignored, although such failure by itself does not exclude the application of article 276 section $1 \mathrm{EPA}$. One should agree with a view presented in the justification of the resolution of seven justices of the Supreme Administrative Court of 21 December $1998^{14}$, stating that an entity should not be held liable for not holding the required permit only in an exceptional situation; before finding an entity not to be liable, each case needs to be examined individually,

13 The Code of Administrative Proceedings of 14 June 1960, Journal of Laws of 2013, item 267 with amendments; hereinafter referred to as CAP.

14 OPS 13/98. 
considering all the relevant facts. Only once all the facts are jointly examined, can a conclusion be made that the calculation and imposition of the increased fee infringes the constitutional principle of the democratic rule of law (article 2 of the Polish Constitution), and the related principle of citizens' trust in the state and the law it enacts, as well as the principle of legal certainty, the principle of justice, and the principle of the just rule of law (article 7 of the Constitution). The circumstances that need to be examined include whether or not an entity exploiting the environment held in the preceding period the permit to operate an installation, within the meaning of article 180 in conjunction with article $181 \mathrm{EPA}$, the date of filing an application for the new permit and meeting the requirements referred to in the application, the course of proceedings in the case, and the non-infringement of the general principles of the environmental law, including in particular, the principle of sustainable development (article 3 point $50 \mathrm{EPA}$ ), the principle of comprehensiveness of protection (article $5 \mathrm{EPA}$ ), the principle of prevention and caution (article $6 \mathrm{EPA}$ ), and the "polluter pays" principle (article 7 EPA). Furthermore, the operation of an installation should satisfy the principle of best available technology, within the meaning of article 3 point 10 in conjunction with article 207 EPA.

Fourthly, the Court identifies other circumstances that a competent administration body should examine when issuing a decision on the increased fee under the procedure provided for in article 276 section 1 EPA. An administration body should not only examine whether an entity exploiting the environment applied for the permit, if the application was complete, and when the application was filed, but also whether the decision was non-final or final but challenged in the administrative court.

This means that when examining the "absence of a required permit", not only linguistic, but also a systemic and purposive interpretation should be applied. For it cannot be ruled out a priori in all situations that the cause of the absence of a required permit is irrelevant. An entity exploiting the environment that starts operating an installation before commencing its activity must obviously hold the permit for releasing substances or energy to the environment, pursuant to article 180 and $181 \mathrm{EPA}$, which was issued at its request by a competent environmental protection body. The reason why such an entity holds no permit cannot justify the commencement of its activity as the entity cannot enjoy a privileged legal situation as regards the payment of the environmental fees. 


\section{Karolina Szuma}

Fifthly, pursuant to article 162 paragraph $1 \mathrm{CAP}$, an administrative decision terminates in three situations: (i) where it expires, (ii), where it becomes irrelevant, and (iii) where it was issued subject to the satisfaction of a specified condition by a party and the condition was not met within the prescribed time. The body that issued the decision in the first instance should pronounce the decision to have terminated in situation (ii) and (iii). As regards situation (i), the administrative body does not need to pronounce the decision to have terminated, as it is clearly indicated in its wording that after the lapse of a specified time the decision expires and is no longer binding.

It should be noted, that under article 193 section 1 point 1 and 193 section $3 \mathrm{EPA}$ the termination of a permit needs to be pronounced by way of an administrative decision, also after "the lapse of the period for which it was issued". In this situation, having assumed the "reasonableness of the legislators", a question needs to be raised about the ratio legis of this regulation. Was it only the intention to strengthen the certainty of the law by clearly and unambiguously stating when a decision terminates? Or did the legislators also want to achieve other ends? Article 193 section 4 EPA clearly states that "a decision pronouncing a permit to have terminated shall not be issued where the installation operator has obtained a new permit". As a result, although the grounds specified in article 193 section 1 EPA are met for a decision to terminate, including expiry, where a new permit is issued, the existing permit is not pronounced to have expired as it has simply terminated because of the lapse of the time for which it was issued. The legislature found it unnecessary to pronounce the existing permit to have terminated if after its expiry, but before a decision pronouncing its termination, a new permit is issued. Therefore, as long as the applicant files an application for the new permit well in advance, before the expiry of the existing permit, and allowing enough time for the application to be processed, and the new permit is not issued before the expiry of the existing one because of reasons attributable to the administrative body (such as its inaction or tardy proceedings), the issuance of a decision, referred to in article 193 section $4 \mathrm{EPA}$, is relevant for the holder of the existing permit. What follows is that the environmental fee should be paid at the rate applicable during the period of the previous permit from the moment of its expiry until a new one is obtained. It may therefore be found inadmissible to make an entity liable for the tardiness of administrative proceedings by imposing on it the increased environmental fees. 
As the Court points out, whether this is the case, it is also important that an entity exploiting the environment may seek damages from an administrative body for a failure to issue a decision, including the amount of any increased fees, pursuant to article $417^{1}$ paragraph 3 of the Civil Code. However, if such damages are awarded, the measures provided for in the Act on the Financial Liability of Officers of the State for Flagrant Violations of Law of 20 January $2011^{15}$ may be deployed. By amending article 37 paragraph $2 \mathrm{CAP}$, the act imposes an obligation on a body considering a legal measure intended to counteract the inaction of a body conducting proceedings to examine whether a failure to dispose of a matter in a timely manner involved a flagrant violation of law, if it finds taking the measure to be legitimate and decides to take the actions under this provision. This is intended to allow for claiming damages from a public officer in the amount equal to the damages paid by the entity to a party liable for a loss suffered when exercising public authority, not greater, however, than the officer's monthly remuneration multiplied by a factor of 12 .

For the reasons discussed above, the environmental fee for a period in which, for reasons lying with the administrative body, the previous permit is expired (but not pronounced to have terminated by the competent body), but no new permit has been issued, is to be paid at the same rate as in the period covered by the previous permit.

As argued previously, each similar case should be analysed individually, considering why no permit was obtained, whether the entity exploiting the environment applied for the new permit, and whether the cause of the absence of permit is connected with the actions of the body concerned when examining the entity's application for the new permit. This therefore applies to a situation where an application for the new permit was filed and it is necessary to examine the application against statutory requirements and to establish whether the applicable regulations provide for a time limit for the grant of the permit, as it is the case with the integrated permit, which needs to be granted within six months from the application date, under article 209 section 2 EPA. When an entity exploiting the environment files an application for the permit, it should consider how much time is necessary to actually obtain it, taking into account the legal requirements

15 Journal of Laws, No 34, item 173. 


\section{Karolina Szuma}

for the operation of the installation concerned, including, but not limited to, the type and scale of the activity conducted in it.

\section{Bibliography}

Gruszecki K., Komentarz do art. 276 ustawy - Prawo ochrony środowiska, Lex el. 1 June 2011.

Kiersnowska-Drzewiecka A., Optaty za korzystanie ze środowiska jako koszt uzyskania przychodów, Doradca Podatkowy 2013, No 2.

Łuczak K., Glosa do uchwaty NSA z dnia 12 grudnia 2011 r., II OPS 2/11, Glosa 2012, No 4.

Odpowiedzialnośc administracji $i$ w administracji, eds. M. Stahl, Z. Duniewska, Warszawa 2013.

Parchomiuk J., Odpowiedzialność odszkodowawcza za legalne dziatania administracji publicznej, Warszawa 2007.

Sadowski P., Optata podwyższona jakokonsekwencjabrakupozwolenia wodnoprawnego, Casus 2009, No 4.

\section{Email}

karolinaszuma@gmail.com 